\title{
Larval distribution of offshore spawning flatfish in the Gulf of Alaska: potential transport pathways and enhanced onshore transport during ENSO events
}

\author{
Kevin M. Bailey* ${ }^{*}$, Susan J. Picquelle \\ NOAA Alaska Fisheries Science Center, 7600 Sand Point Way NE, Seattle, Washington 98115, USA
}

\begin{abstract}
Offshore and deepwater spawning flatfish species in the Gulf of Alaska, such as arrowtooth flounder Atheresthes stomias and Pacific halibut Hippoglossus stenolepis, have juvenile nurseries that are inshore, in bays or at the mouths of bays. Larvae must emigrate from their spawning areas along the continental slope and outer shelf towards shore, in a direction across the prevailing Alaskan Stream. Using a 20 yr time series of data from ichthyoplankton surveys in the Gulf of Alaska, we examine patterns of variability in larval halibut and flounder distributions that may reflect processes resulting in successful recruitment to nursery areas. Several patterns can be observed in these data. Eggs and the smallest-sized larvae are distributed deep in the water column along the outer shelf and slope. Larger larvae tend to be located in the upper water column and farther inshore over the continental shelf. Larger larvae are also associated with deep-sea valleys and troughs that penetrate the shelf. Thus, these topographic features may serve as transport pathways to juvenile nursery grounds. ENSO (El Niño-Southern Oscillation) conditions and warm-year anomalies are linked to recruitment strength of Pacific halibut. Variability in larval transport as related to ENSO and other conditions that enhance onshore advection may play an important role in the recruitment of flatfishes to their nursery grounds. The results of this analysis indicate that larvae of both species are more abundant in coastal areas during El Niño events, and that a higher proportion of larvae are transported inshore during El Niño years.
\end{abstract}

KEY WORDS: Larval transport · Pacific halibut $\cdot$ Arrowtooth flounder $\cdot$ Marine fish larvae $\cdot$ Currents Resale or republication not permitted without written consent of the publisher

\section{INTRODUCTION}

Larval transport is one of the key processes in the recruitment of marine fish populations (Parrish et al. 1981) and is also a determinant of population structure (Doherty et al. 1995, Stepien 1999). For some marine species, spawning occurs in the vicinity of suitable nursery habitats, and retention of eggs and larvae is a favorable condition for recruitment (Sinclair 1988). Other species may spawn outside of nursery areas, and successful recruitment depends on transport to the

*E-mail: kevin.bailey@noaa.gov nursery habitat (Van der Veer et al. 1998, Van der Veer \& Witte 1999). Offshore spawning flatfish species whose juvenile nurseries are inshore are of the latter type, and in general, most flatfish species have juvenile nurseries that are inshore of the spawning area (Minami \& Tanaka 1992).

Arrowtooth flounder Atheresthes stomias and Pacific halibut Hippoglossus stenolepis share several critical life history attributes. In the Gulf of Alaska, they spawn their eggs offshore over the outer continental shelf and slope, and deep in the water column of the Alaskan Stream in late winter (Fig. 1; Thompson \& Van Cleve 1936, St. Pierre 1989, Rickey 1995). Both species have 


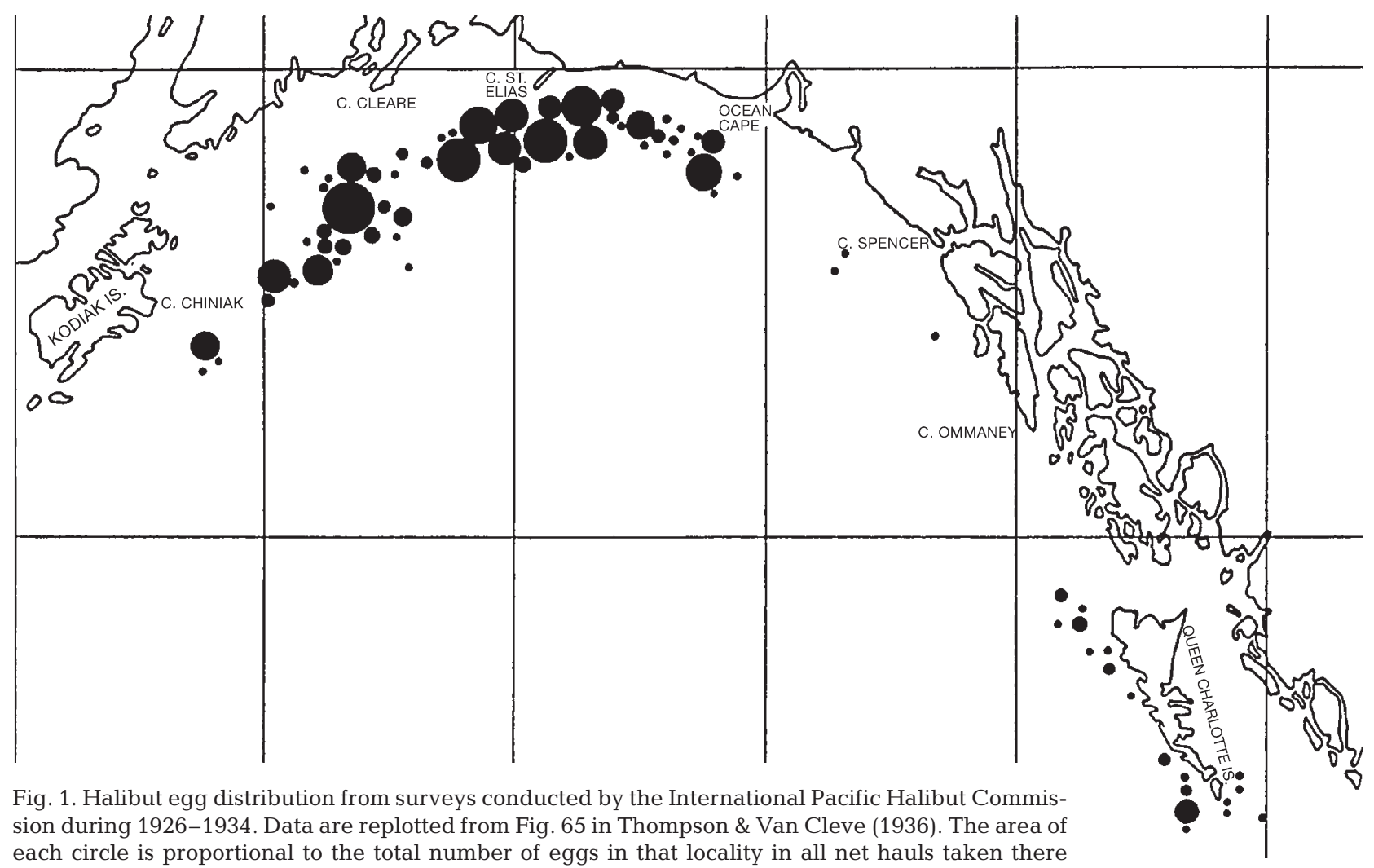

juvenile nurseries that are inshore in bays or at the mouths of bays (Norcross et al. 1999). In the Gulf of Alaska, surface currents are dominated by the Alaska Coastal Current and the offshore Alaskan Stream (Fig. 2). Both of these currents are vigorous and are steered by coastal topography. To get inshore, halibut and flounder larvae need to move in a direction across these dominant surface currents. Deep water currents are less well known but literature indicates that bottom water flows up the sea valleys (Lagerlof 1983), although this may be influenced by tides, Kelvin waves, sea level and upwelling.

a

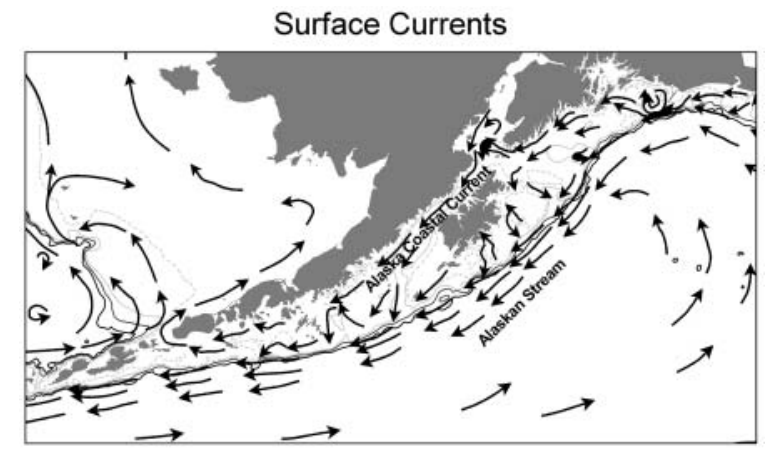

We have used a 20 yr time series of ichthyoplankton data in the Gulf of Alaska to evaluate patterns in the distribution of Atheresthes stomias and Hippoglossus stenolepis larvae. The vertical distribution of larvae was examined from vertically stratified Tucker and MOCNESS samples. The geographic distribution of different stages of larvae was examined from bongo, Methot and Tucker tows. Distribution of larvae was examined in relation to topographic features within characteristic strata, including strata with dominant sea valleys, and distance offshore. We have further tested whether larvae are more abundant and whether

Fig. 2. Synthesis of (a) surface currents (adapted from Stabeno et al. 1996), and (b) currents at 100 to $400 \mathrm{~m}$ in the northern and western Gulf of Alaska 
a higher proportion of larvae are found inshore during El Niño years.

\section{MATERIALS AND METHODS}

The data used to describe the geographic distribution of Atheresthes stomias and Hippoglossus stenolepis larvae were collected on 47 ichthyoplankton cruises (Table 1), conducted by either the Alaska Fisheries Science Center (AFSC) or jointly with Soviet, Korean, and Japanese fisheries research agencies. These cruises occurred between February and July in the years 1972, 1978, 1979, and 1981 to 1996, primarily in the Gulf of Alaska. Cruises were selected from our database (ICHBASE) of over 100 cruises based on their geographical and seasonal coverage. The season of interest was determined by examining catch rates of both species by month from all cruises in ICHBASE that occurred in the Gulf of Alaska. After selecting only cruises that met the season (February through July) and geographic (Gulf of Alaska) criteria, the remaining 47 cruises contain 4810 bongo $(60 \mathrm{~cm}$ diameter) tows, 230 Methot (2 m width) tows, and 292 Tucker $(1 \mathrm{~m}$ width) tows, for a total of 5332 tows. The cruises used in this analysis were conducted for many purposes; however, none of them were designed specifically to describe the spatial distribution of flatfish. Adequate spatial and seasonal coverage was accomplished by pooling cruises over year. All tows were quantitative and oblique and were conducted in a standardized manner with attached flowmeters. Samples were preserved in $5 \%$ formalin and sorted to species at the Polish Plankton Sorting Center, Szechin, Poland. A subsample of larvae was measured for length composition (standard lengths, SL).

Vertical distribution of larvae was determined from multiple series of MOCNESS and Tucker tows, and analyzed separately. Tow depths were variable, but usually to $200 \mathrm{~m}$ or deeper. The mean depth and variance for each species and length class of larvae was determined as follows. For each station, the average depth of each vertically stratified net sample and number of larvae in each net was used to calculate the mean depth of larvae for the station. The average and variance over all tows for each gear type was calculated from the mean depth of larvae at each station weighted by larval abundance.

Transport of larvae was inferred by comparing spatial distributions of larvae of 3 different length intervals. Atheresthes stomias larvae were classified as small ( $<7 \mathrm{~mm} \mathrm{SL})$, medium ( 7 to $10 \mathrm{~mm} \mathrm{SL}$ ), and large $(>10 \mathrm{~mm})$. The same 3 classifications were assigned to Hippoglossus stenolepis larvae using the length intervals $<13,13$ to 18 , and $>18 \mathrm{~mm}$. The length intervals used for each species were based on the approximate

Table 1. Cruises used in analysis. Asterisks next to the year indicate El Niño conditions. Dates are given dd/mm/yy

\begin{tabular}{|c|c|c|c|c|c|}
\hline Year & Cruise & Stations & Start date & End date & Gear \\
\hline 1972 & 2KE72 & 66 & $26 / 4 / 72$ & $9 / 5 / 72$ & Bongo \\
\hline 1978 & 4DI78 & 85 & $29 / 3 / 78$ & $20 / 4 / 78$ & Bongo \\
\hline 1978 & 2MF78 & 89 & $20 / 6 / 78$ & $5 / 7 / 78$ & Bongo \\
\hline 1979 & 1MF79 & 88 & $14 / 2 / 79$ & $8 / 3 / 79$ & Bongo \\
\hline 1979 & $5 \mathrm{TK} 79$ & 58 & $16 / 5 / 79$ & $24 / 5 / 79$ & Bongo \\
\hline 1981 & 1SH81 & 131 & 5/3/81 & $30 / 3 / 81$ & Bongo \\
\hline 1981 & 2MF81 & 89 & $30 / 3 / 81$ & $8 / 4 / 81$ & Bongo \\
\hline 1981 & 2SH81 & 60 & $16 / 4 / 81$ & $24 / 4 / 81$ & Bongo \\
\hline 1981 & 3MF81 & 79 & $26 / 4 / 81$ & $2 / 5 / 81$ & Bongo \\
\hline 1981 & $4 \mathrm{MF} 81$ & 80 & $20 / 5 / 81$ & $24 / 5 / 81$ & Bongo \\
\hline 1981 & 3SH81 & 56 & $20 / 5 / 81$ & $28 / 5 / 81$ & Bongo \\
\hline 1982 & 1DA82 & 82 & $4 / 4 / 82$ & $23 / 4 / 82$ & Bongo \\
\hline 1982 & 2DA82 & 62 & $21 / 5 / 82$ & $31 / 5 / 82$ & Bongo \\
\hline $1983^{*}$ & 1CH83 & 68 & $14 / 5 / 83$ & $30 / 5 / 83$ & Bongo \\
\hline 1984 & 1SH84 & 157 & 7/4/84 & $4 / 5 / 84$ & Bongo \\
\hline 1985 & 1DI85 & 69 & $11 / 3 / 85$ & $28 / 3 / 85$ & Bongo \\
\hline 1985 & 1PO85 & 154 & 29/3/85 & $21 / 4 / 85$ & Bongo \\
\hline 1985 & 2PO85 & 188 & $16 / 5 / 85$ & 8/6/85 & Bongo \\
\hline 1986 & 1GI86 & 147 & $30 / 3 / 86$ & $20 / 4 / 86$ & Bongo \\
\hline 1986 & 1MF86 & 81 & $4 / 4 / 86$ & $12 / 4 / 86$ & Bongo \\
\hline $1987^{*}$ & 2MF87 & 143 & $4 / 4 / 87$ & $16 / 4 / 87$ & Bongo \\
\hline $1987^{*}$ & 1BB87 & 117 & $9 / 4 / 87$ & $27 / 4 / 87$ & Bongo \\
\hline $1987^{*}$ & 4MF87 & 170 & $18 / 6 / 87$ & $16 / 7 / 87$ & Methot \\
\hline 1988 & $10 \mathrm{C} 88$ & 61 & $17 / 3 / 88$ & $4 / 4 / 88$ & Bongo \\
\hline 1988 & 1DN88 & 203 & $19 / 3 / 88$ & $8 / 5 / 88$ & Bongo \\
\hline 1988 & $4 \mathrm{MF} 88$ & 199 & $20 / 5 / 88$ & $7 / 6 / 88$ & 193 Tucker, 6 bongo \\
\hline 1989 & 1MF89 & 128 & 6/4/89 & $15 / 4 / 89$ & Bongo \\
\hline 1989 & 2MF89 & 91 & $26 / 4 / 89$ & $5 / 5 / 89$ & Bongo \\
\hline 1989 & 3MF89 & 211 & 9/5/89 & $24 / 5 / 89$ & Bongo \\
\hline 1989 & 4MF89 & 103 & 29/5/89 & $5 / 6 / 89$ & 99 Tucker, 4 bongo \\
\hline 1990 & 1MF90 & 107 & $8 / 4 / 90$ & $13 / 4 / 90$ & Bongo \\
\hline 1990 & 2MF90 & 89 & $7 / 5 / 90$ & $15 / 5 / 90$ & Bongo \\
\hline 1990 & 4MF90 & 133 & $28 / 5 / 90$ & $5 / 6 / 90$ & Bongo \\
\hline 1991 & 1MF91 & 90 & 2/4/91 & 13/4/91 & Bongo \\
\hline 1991 & 2MF91 & 148 & 16/4/91 & 27/4/91 & Bongo \\
\hline 1991 & 3MF91 & 119 & $1 / 5 / 91$ & $13 / 5 / 91$ & Bongo \\
\hline 1991 & 4MF91 & 97 & $17 / 5 / 91$ & $25 / 5 / 91$ & Bongo \\
\hline 1991 & 5MF91 & 60 & 23/7/91 & $31 / / 91$ & Methot \\
\hline $1992^{*}$ & 3MF92 & 157 & $2 / 5 / 92$ & $14 / 5 / 92$ & Bongo \\
\hline $1992^{*}$ & 4MF92 & 137 & $18 / 5 / 92$ & $28 / 5 / 92$ & Bongo \\
\hline $1993^{*}$ & 2MF93 & 96 & $6 / 4 / 93$ & $11 / 4 / 93$ & Bongo \\
\hline $1993^{*}$ & 4MF93 & 141 & $3 / 5 / 93$ & $13 / 5 / 93$ & Bongo \\
\hline $1993^{*}$ & 5MF93 & 114 & $23 / 5 / 93$ & $3 / 6 / 93$ & Bongo \\
\hline 1994 & 5MF94 & 89 & $2 / 5 / 94$ & $15 / 5 / 94$ & Bongo \\
\hline 1995 & 8MF95 & 98 & $21 / 5 / 95$ & 28/5/95 & Bongo \\
\hline $1996^{*}$ & 1DI96 & 154 & $26 / 4 / 96$ & $6 / 5 / 96$ & Bongo \\
\hline $1996^{*}$ & 6MF96 & 188 & $2 / 5 / 96$ & $15 / 5 / 96$ & Bongo \\
\hline \multicolumn{2}{|c|}{$\begin{array}{l}\text { Total number } \\
\text { of stations }\end{array}$} & 5332 & & & \\
\hline
\end{tabular}


number of larvae in each length range in order to ensure adequate numbers in each category.

To test for the impact of El Niño events on larval distributions, the cruises were divided into 2 groups before pooling over years: El Niño years (1983, 1987, 1992, 1993 and 1996) and non-El Niño years (1972, 1978, 1979, 1981, 1982, 1984 to 1986,1988 to 1991, 1994 and 1995). The El Niño and non-El Niño years were classified from their effects in the northern Gulf of Alaska during the late-winter and spring period (Bailey et al. 1995). For example, the 1982-83 El Niño did not affect the northern Gulf of Alaska until winter 1983. The mean spatial distribution for the 3 length ranges of each species and for El Niño and non-El Niño years was represented by a series of maps. The area surveyed by the cruises was gridded into $20 \times 20 \mathrm{~km}$ cells. Mean catch $10 \mathrm{~m}^{-2}$ was calculated for each grid cell, averaging over all stations that fell within the cell from all cruises that occurred during the subset of years for either El Niño or non-El Niño years.
To further examine changes in larval distribution associated with El Niño conditions, the study area was divided into 7 strata based on bathymetry and longitude (Fig. 3). One stratum is the offshore stratum, and its inshore boundary is the $500 \mathrm{~m}$ depth contour. This stratum is where spawning occurs for both species. The inshore area is divided into 3 shelf strata and 3 sea-valley strata. The shelf area is primarily shallower than $200 \mathrm{~m}$ and the 3 strata correspond to broad longitudinal ranges. The Shelikof Strait sea valley was divided into 2 strata, the inner sea valley and outer sea valley. The third sea valley stratum is north of Kodiak Island and consists of a shelf region bisected by 2 troughs. We hypothesize that the outer Shelikof Strait sea valley and upper shelf/sea valley strata provide routes for the larvae spawned offshore to be transported to their inshore nursery grounds.

As an exploratory method to examine relative onshore transport, the density of larvae in each stratum for each size category and species was compared to the

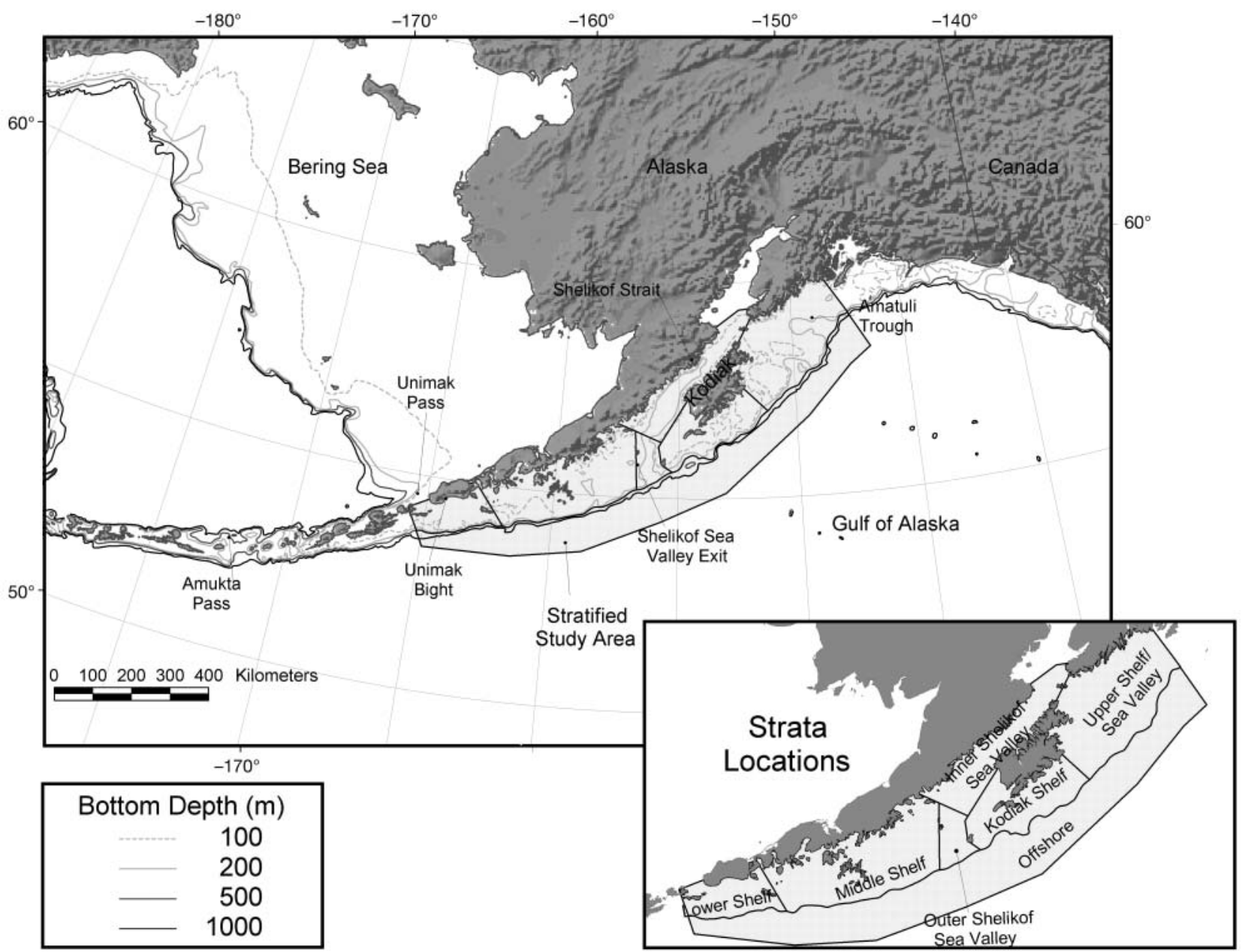

Fig. 3. Stratified study area and key landmarks in the Gulf of Alaska. Inset map shows strata boundaries and labels 
density of larvae found in the offshore strata. The density in each stratum relative to the density in the offshore stratum is a measure of the success of larvae moving onshore from the offshore stratum where they were spawned. If the relative densities change under El Niño conditions, then one can infer that larval transport was impacted by these conditions. Hypotheses were tested for each stratum and size group using generalized linear models (GLM function in S-Plus 2000). The null hypothesis was that there was no effect of El Niño on the stratum density relative to the offshore stratum density. This hypothesis was tested by fitting 2 generalized linear models to the densities from the 2 strata. The first model includes a grand mean, a stratum effect, and an El Niño effect. The second model added another effect - the stratum $\times$ El Niño interaction term. If the interaction term is significant, then the difference in the densities from the 2 strata varies with El Niño; that is, the relative density of the stratum compared to the density of the offshore stratum is different during El Niño conditions. The significance of the interaction term was tested by computing the difference in the residual deviances for these 2 models and testing to see if the difference is significantly greater than 0 . Under the null hypothesis, the difference in the residual deviances is distributed as a Chi-square random variable. A Bonferroni correction was performed to control the experiment-wise error rate for each species. There were 18 comparisons (6 strata paired with the offshore stratum and 3 length intervals), thus the Type I error rate was conservatively preserved by dividing the desired error rate by 18 for each comparison. (The comparisons for Hippoglossus stenolepis actually consisted of only 17 hypothesis tests because no small larvae were captured in the lower shelf stratum, thus precluding a test of that stratum, so the error rate was divided by 17 instead of 18 .)

The results of each hypothesis test were visualized with a bar chart of the relative density for each stratum, standardized to the offshore stratum, for El Niño and non-El Niño years. The relative density was computed by dividing the mean catch $10 \mathrm{~m}^{-2}$ data for each stratum by the mean catch $10 \mathrm{~m}^{-2}$ in the offshore stratum, averaged over either El Niño or non-El Niño years. For a particular stratum, if the hypothesis test was significant and the bar chart showed that the relative density was higher during El Niño than non-El Niño years, then one can infer that transport from the offshore stratum to the stratum being examined was more successful during El Niño years.

The time series of Hippoglossus stenolepis recruitment was provided by the International Pacific Halibut Commission.

\section{RESULTS}

\section{Size range and monthly abundance trends}

The monthly abundances of Atheresthes stomias and Hippoglossus stenolepis from all bongo, Tucker and Methot tows from the Gulf of Alaska in the ICHBASE
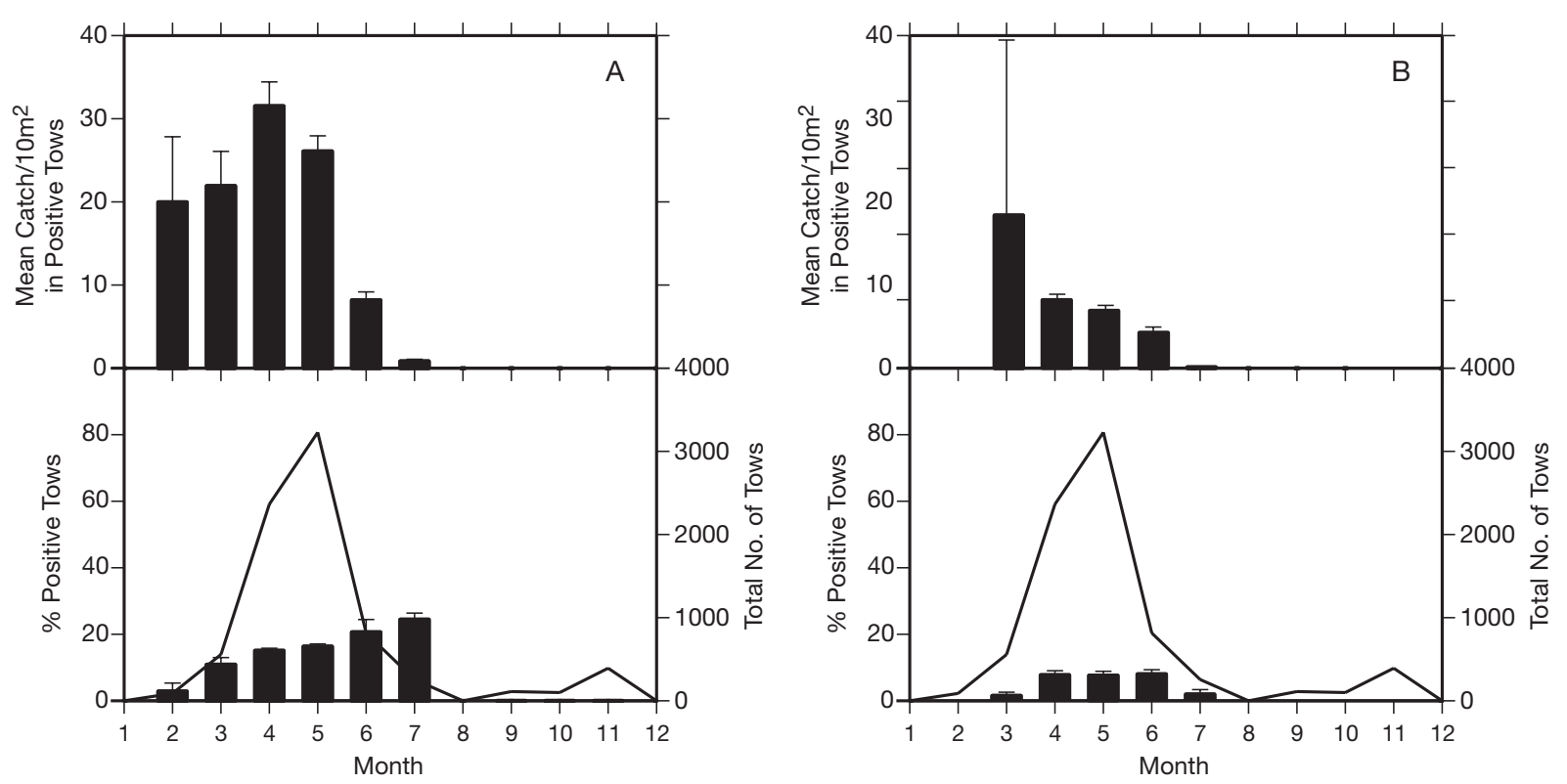

Fig. 4. (A) Seasonal abundance of Atheresthes stomias larvae in the Gulf of Alaska. Error bars are SE of the mean. Line graph shows the number of tows $\mathrm{mo}^{-1}$. (B) Seasonal abundance of Hippoglossus stenolepis larvae in the Gulf of Alaska. Error bars are $\mathrm{SE}$ of the mean. Line graph shows the number of tows $\mathrm{mo}^{-1}$ 

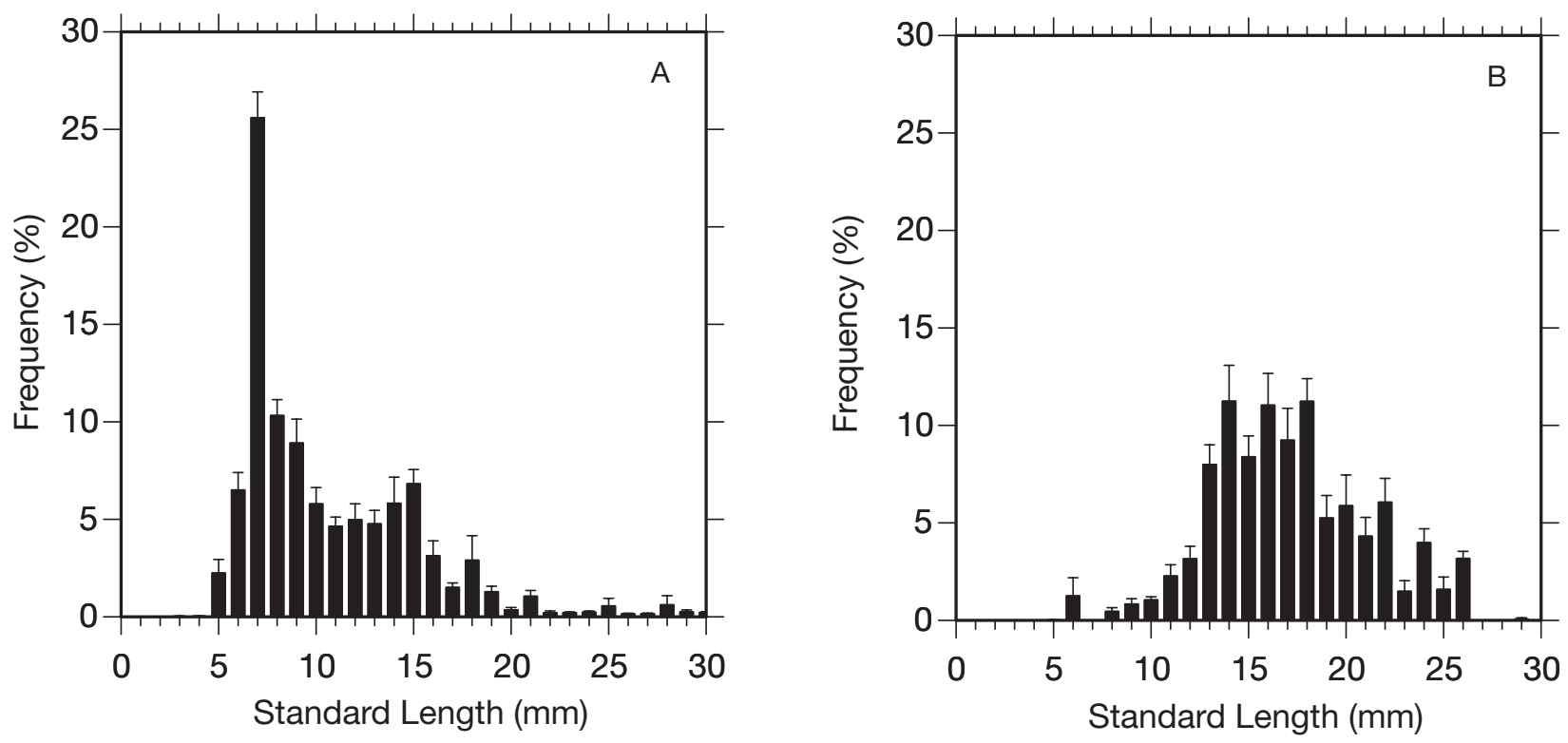

Fig. 5. (A) Size distribution of Atheresthes stomias larvae in the Gulf of Alaska study area. Error bars are SE of the mean; $\mathrm{n}=5635$. (B) Size distribution of Hippoglossus stenolepis larvae in the Gulf of Alaska study area. Error bars are SE of the mean; $\mathrm{n}=901$

database are shown in Fig. 4. A. stomias larvae are most abundant from February to July, with a peak abundance in April and May (Fig. 4A). H. stenolepis larvae are most abundant from March to June with a peak abundance in March, April and May (Fig. 4B).

Size ranges for both species were based on the data from the 47 cruises used in the analysis, not all cruises in the Gulf of Alaska as was used to determine seasonal patterns. Atheresthes stomias larvae range in size from 5 to $30 \mathrm{~mm}$ with a peak abundance at 7 to $9 \mathrm{~mm}$ (Fig. 5A). Hippoglossus stenolepis larvae range in size from 6 to $29 \mathrm{~mm}$, with a peak in abundance at 13 to $18 \mathrm{~mm}$ (Fig. 5B).

\section{Vertical distribution}

The vertical distribution of Atheresthes stomias and Hippoglossus stenolepis larvae was analyzed from vertical series of Tucker and MOCNESS tows by size class of larvae integrated over all geographic areas. The smallest size categories of both $A$. stomias and $H$. stenolepis larvae are found deep in the water column (Fig. 6). Small A. stomias larvae are 100 to $150 \mathrm{~m}$ deep, and $H$. stenolepis are considerably deeper at 200 to $300 \mathrm{~m}$. For the intermediate size classes, both species show evidence of migrating towards the surface. A. stomias larvae are from 50 to $100 \mathrm{~m}$, and H. stenolepis larvae are centered at about $50 \mathrm{~m}$. For the largest size category of larvae, both species are in the upper $50 \mathrm{~m}$ of the water column. H. stenolepis eggs were not col-
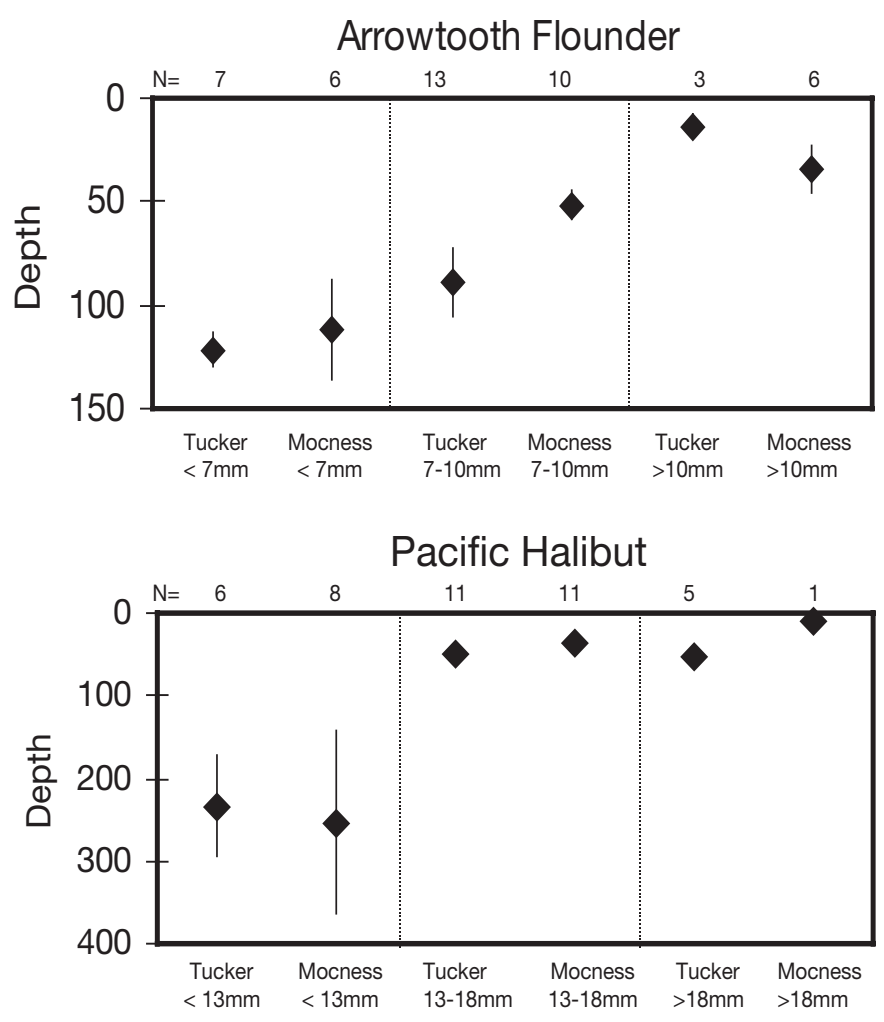

Fig. 6. Vertical distribution of Atheresthes stomias (upper panel) and Hippoglossus stenolepis (lower panel) larvae in the Gulf of Alaska study area. Composite data are shown for each size category and species as mean weighted depth for Tucker and MOCNESS tows. Error bars are SE of the mean. Number of vertical tow series used in the calculations for each gear type and size category is given at the top of each panel 
lected in our surveys, and A. stomias egg identification is uncertain.

\section{Geographic aspects of larval distribution: effects of El Niño conditions}

Ichthyoplankton surveys that covered a broad geographical extent were selected from ICHBASE to examine the geographical distribution of larvae. Surveys were categorized as El Niño or non-El Niño years based on the prevalence of El Niño conditions at the time of the survey. Figs. $7 \& 8$ show the geographic distribution of mean densities in $20 \times 20 \mathrm{~km}$ cells of the 2 larger size categories for each species in El Niño and non-El Niño conditions. Maps of the smallest size class are not presented because our surveys may not have sampled the small larvae adequately due to their offshore distribution.

Atheresthes stomias and Hippoglossus stenolepis show similar larval distribution patterns. From visual examination of distribution maps, most larvae of both species are located along the outer shelf and slope. Larger larvae tend to be located farther inshore over

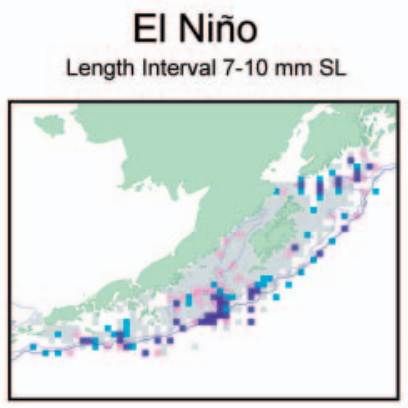

Non El Niño

Length Interval 7-10 $\mathrm{mm} \mathrm{SL}$
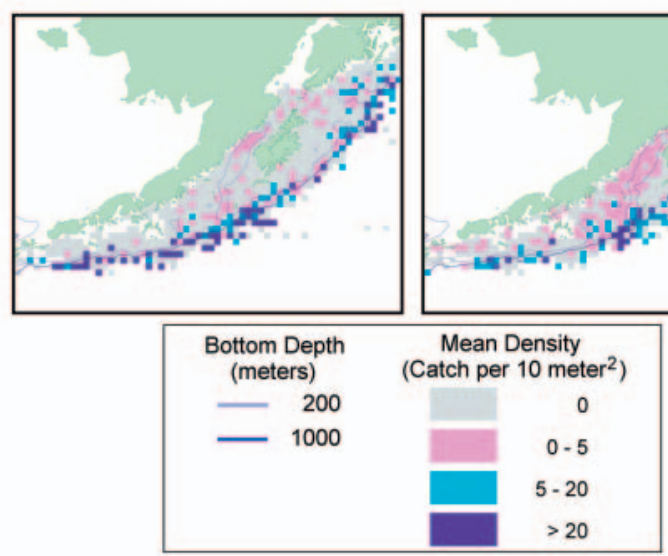

Fig. 7. Geographic distribution of Atheresthes stomias larvae for the 2 larger size class ( 7 to $10,>10 \mathrm{~mm}$ ) in El Niño and non-El Niño years the continental shelf. For both species, larger larvae are also associated with deep-sea valleys and trough systems that penetrate the shelf, especially the Amatuli Trough and outer Shelikof sea valley. In El Niño years, larger larvae are much more abundant in the Amatuli Trough, outer Shelikof sea valley and Unimak Bight regions. This pattern is consistent for both species. In El Niño years, large $H$. stenolepis larvae are especially more abundant in the Unimak Bight area.

To further examine changes in larval distribution associated with El Niño conditions, the mean densities of larvae in several different topographically determined strata were calculated. For Atheresthes stomias the mean densities are significantly higher in almost all strata and all size categories in El Niño years (Table 2). Apart from the offshore densities, the highest mean densities are over the lower shelf region, the outer Shelikof Strait sea valley region and over the upper shelf/sea valley region for the intermediate and largest size classes. The smallest size class of larvae is rare except in the offshore region.

The density of larvae in each stratum for each size category and species was standardized to the number of larvae found in the offshore stratum. This standard-

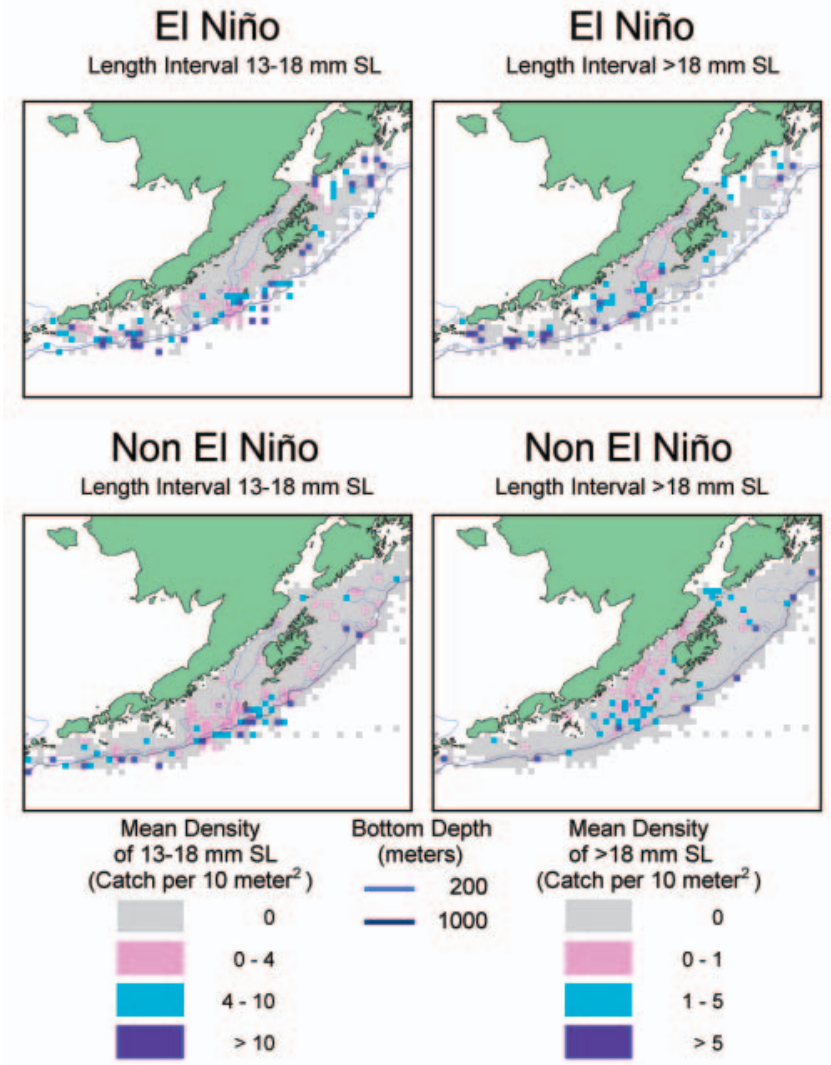

Fig. 8. Geographic distribution of Hippoglossus stenolepis larvae for the 2 larger size class (13 to $18,>18 \mathrm{~mm}$ ) in El Niño and non-El Niño years 
Table 2. ANOVA of the El Niño effect on mean densities of Atheresthes stomias. Numbers in cells are the densities per $10 \mathrm{~m}^{2} .{ }^{*}$ Significant El Niño effect after Bonferroni correction for multiple tests for an experiment-wise error rate of 0.05: $\alpha=0.05 / 21=0.00238$

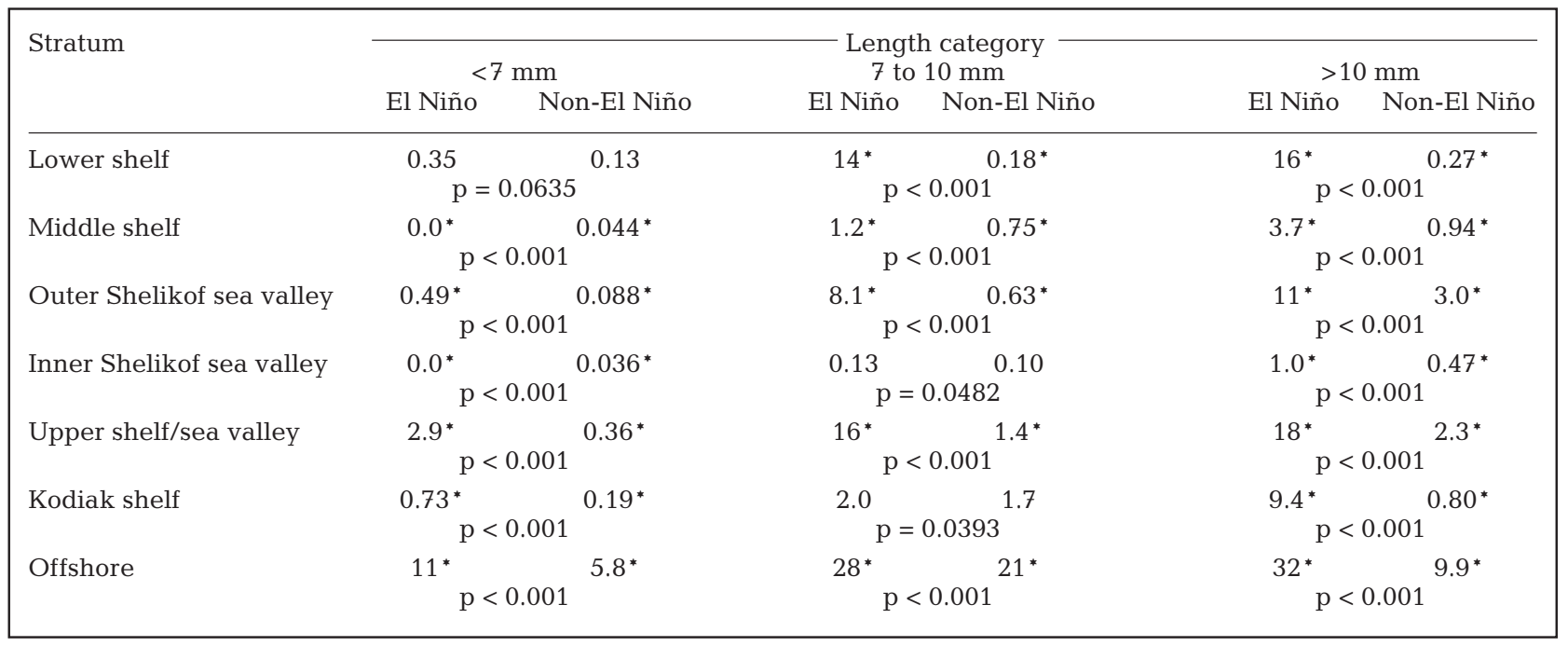

ization is a potential way to explore the relative success of larvae moving onshore (Fig. 9). Since the smallest-sized larvae were relatively rare outside of the offshore stratum, results from this size category are equivocal. Stratum mean densities relative to the offshore stratum density show significant Stratum $\times$ El Niño interactions for the medium-size category of $A$. stomias over the upper-shelf/sea valley, outer Shelikof sea valley and lower-shelf strata (Table 3). These 3 strata had significantly higher relative densities in El Niño years (Fig. 9A). Relatively low mean densities are found over the inner Shelikof sea valley stratum in both time periods. The large larvae show a similar pattern, but with an additional 2 strata with significant differences. These exceptions are the middle shelf with slightly higher relative densities during El Niño years and the inner Shelikof sea valley with slightly lower relative densities in El Niño years.

Hippoglossus stenolepis larvae are most abundant in the offshore stratum, with the exception of the largest size category (Table 4). As with the small larvae, results for the largest size of $H$. stenolepis larvae in most strata should be viewed with some reservations because of their rarity, except in the lower shelf stratum during El Niño years. Apart from the offshore stratum, the highest mean densities for the 2 larger size classes are found over the lower shelf, outer Shelikof sea valley and upper shelf/sea valley.

Statistical tests of an El Niño effect on the relative distribution of Hippoglossus stenolepis larvae in each stratum against the mean density of larvae in the offshore stratum shows a significant effect of El Niño in all strata for the middle-sized larvae (Table 5). This effect is positive and especially pronounced for the Lower Shelf Upper Shelikof Strait sea valley strata (Fig. 9B). The large-size class was not as consistent over strata as the middle-size class. Only the lowershelf strata had significantly higher relative densities in El Niño years. All of the other strata (except the Kodiak shelf stratum) had significantly lower relative densities in El Niño years. However, these results are equivocal due to the rarity of large $H$. stenolepis larvae

Table 3. Generalized linear model comparisons of the mean densities of Atheresthes stomias in each stratum to the mean density of larvae in the offshore stratum in El Niño or non-El Niño years. Numbers in cells are the test statistic (deviance). If the Stratum $\times$ El Niño factor is significant, then the relative densities in these 2 strata change with El Niño conditions. *Significant Stratum $\times$ El Niño effect after Bonferroni correction for multiple tests for an experimentwise error rate of 0.05 : $\alpha=0.05 / 18=0.0028$

\begin{tabular}{|lccc|}
\hline \multirow{2}{*}{ Stratum } & \multicolumn{3}{c|}{ Length category } \\
\cline { 2 - 4 } & $<7 \mathrm{~mm}$ & 7 to $10 \mathrm{~mm}$ & $>10 \mathrm{~mm}$ \\
\hline Lower shelf & 0.51 & $510^{*}$ & $250^{*}$ \\
& $\mathrm{p}=0.475$ & $\mathrm{p}<0.001$ & $\mathrm{p}<0.001$ \\
Middle shelf & $33^{*}$ & 3.5 & $10^{*}$ \\
& $\mathrm{p}<0.001$ & $\mathrm{p}=0.0617$ & $\mathrm{p}=0.0012$ \\
Outer Shelikof & $29^{*}$ & $1150^{*}$ & 4.0 \\
sea valley & $\mathrm{p}<0.001$ & $\mathrm{p}<0.001$ & $\mathrm{p}=0.0461$ \\
Inner Shelikof & $61^{*}$ & 0.048 & $47^{*}$ \\
sea valley & $\mathrm{p}<0.001$ & $\mathrm{p}=0.826$ & $\mathrm{p}<0.001$ \\
Upper shelf/ & $220^{*}$ & $1967^{*}$ & $340^{*}$ \\
sea valley & $\mathrm{p}<0.001$ & $\mathrm{p}<0.001$ & $\mathrm{p}<0.001$ \\
Kodiak shelf & $18^{*}$ & 2.2 & $370^{*}$ \\
& $\mathrm{p}<0.001$ & $\mathrm{p}=0.136$ & $\mathrm{p}<0.001$ \\
\hline
\end{tabular}



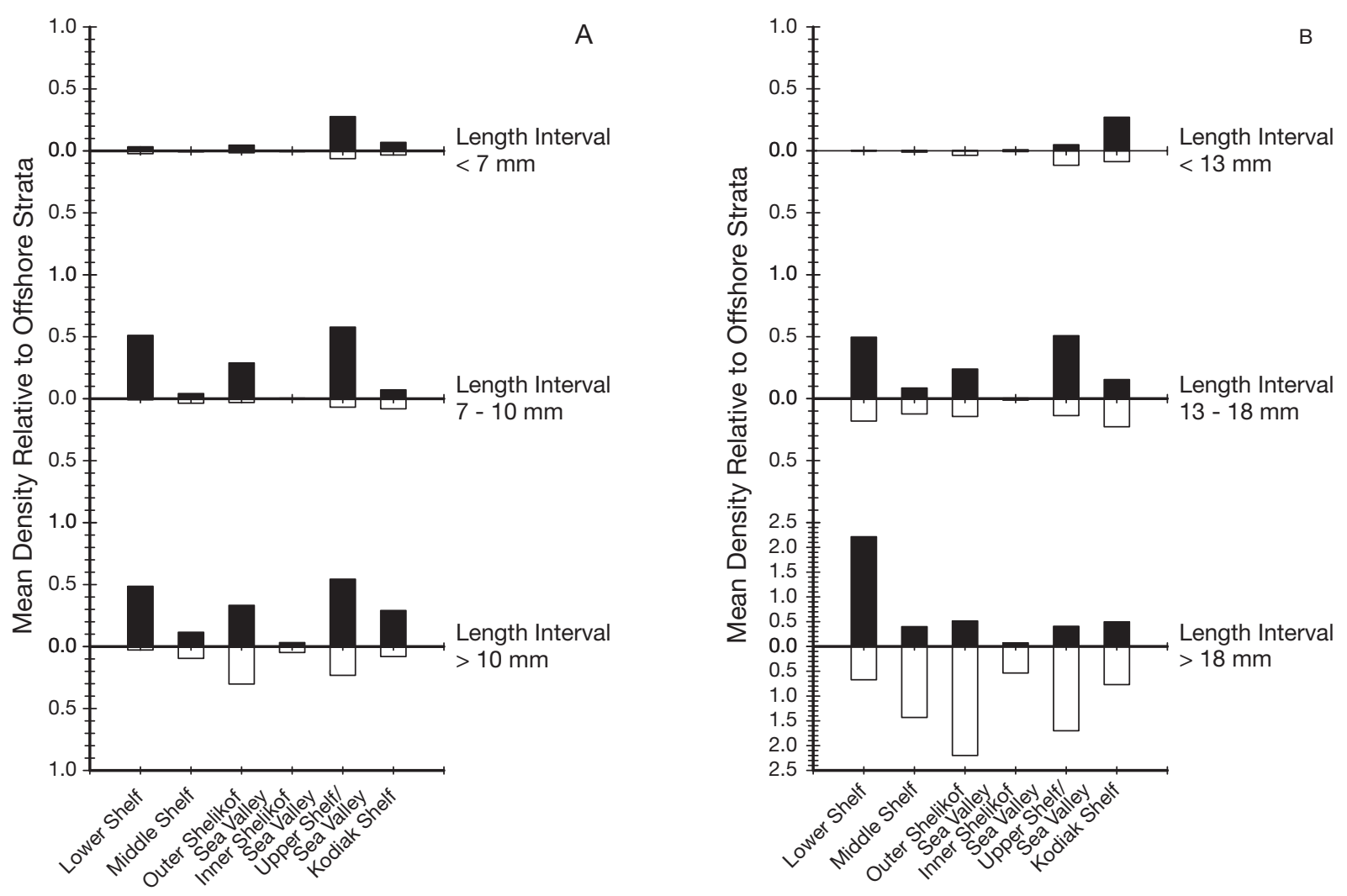

Fig. 9. Relative densities by stratum for each length interval in El Niño (closed bars) and non-El Niño (open bars) years for (A) Atheresthes stomias and (B) Hippoglossus stenolepis larvae. Relative densities are standardized to the mean density in the offshore stratum

(Table 4). The smallest-sized larvae were rare except in the offshore stratum, so we did not pursue this analysis for this size category.

\section{DISCUSSION}

The larval distributions of both Atheresthes stomias and Hippoglossus stenolepis are quite similar. For both species, the smallest-sized larvae are concentrated along the outer shelf and slope. Larger larvae tend to be located farther inshore over the continental shelf. This conclusion is similar to that reached for $H$. stenolepis by Thompson \& Van Cleve (1936). For both species, larger larvae are also associated with deepsea valleys and troughs that penetrate the shelf, especially the Amatuli Trough and the outer sea valley leading to Shelikof Strait, and the Unimak Bight. Literature reports indicate that bottom water flows up these sea valleys. It is also known that at times, surface currents may flow through the Amatuli Trough and through gullies near the Shumagin Islands leading toward the lower-shelf region. These topographic fea- tures may steer nearshore currents, thus serving as transport pathways to juvenile nursery grounds. Although surface flow through the Shelikof Strait sea valley is usually down the valley toward the southwest rather than up it, during El Niño conditions there may be a reversed or relaxed flow with periods of current flow upstrait; this was observed in the El Niño years of 1992 (K. Bailey unpubl. data) and 1996 (Bailey et al. 1999).

For both Atheresthes stomias and Hippoglossus stenolepis the abundance of larvae in our surveys was higher in El Niño years compared with non-El Niño years. For the smallest larvae, the distributions are similar in El Niño and non-El Niño years across the geographic strata. During El Niño conditions, the intermediate and large size-classes of larvae are especially more abundant in the upper-shelf/Amatuli sea valley region, the outer Shelikof Strait sea valley region, and in the lower-shelf/Unimak Bight, possibly indicating enhanced transport onshore and downstream. This concept was supported by analyses where the abundance of larvae in the inshore areas was examined relative to the mean abundance offshore in El Niño and 
Table 4. ANOVA of the El Niño effect on mean densities of Hippoglossus stenolepis. Numbers in cells are the densities per $10 \mathrm{~m}^{2}$. *Significant El Niño effect after Bonferroni correction for multiple tests for an experiment-wise error rate of 0.05: $\alpha=0.05 / 21=0.00238$

\begin{tabular}{|c|c|c|c|c|c|c|}
\hline \multirow{3}{*}{ Stratum } & & & & \multirow{2}{*}{\multicolumn{2}{|c|}{$>18 \mathrm{~mm}$}} \\
\hline & \multicolumn{2}{|c|}{$<13 \mathrm{~mm}$} & & & & \\
\hline & El Niño & Non-El Niño & \multicolumn{2}{|c|}{$\begin{array}{l}\text { Length category } \\
13 \text { to } 18 \mathrm{~mm} \\
\text { El Niño Non-El Niño }\end{array}$} & El Niño & Non-El Niño \\
\hline \multirow[t]{2}{*}{ Lower shelf } & 0.0 & 0.0 & $3.4^{*}$ & $0.47^{*}$ & $2.4^{*}$ & $0.16^{*}$ \\
\hline & \multicolumn{2}{|c|}{$\mathrm{p}=0.437$} & \multicolumn{2}{|c|}{$\mathrm{p}<0.001^{0.4 t}$} & \multicolumn{2}{|c|}{$\mathrm{p}<0.001$} \\
\hline \multirow{2}{*}{ Middle shelf } & 0.0 & 0.0092 & $0.59^{*}$ & $0.32^{*}$ & 0.43 & 0.34 \\
\hline & \multicolumn{2}{|c|}{$p=0.0352$} & \multicolumn{2}{|c|}{$p<0.001$} & \multicolumn{2}{|c|}{$p=0.0319$} \\
\hline \multirow[t]{2}{*}{ Outer Shelikof sea valley } & $0.0^{*}$ & $0.032^{*}$ & $1.6^{*}$ & $0.38^{*}$ & 0.56 & 0.52 \\
\hline & \multicolumn{2}{|c|}{$p=0.00129$} & \multicolumn{2}{|c|}{$\mathrm{p}<0.001$} & \multicolumn{2}{|c|}{$p=0.568$} \\
\hline \multirow[t]{2}{*}{ Inner Shelikof sea valley } & 0.0083 & 0.0057 & 0.027 & 0.032 & $0.080^{*}$ & $0.13^{*}$ \\
\hline & \multicolumn{2}{|c|}{$\mathrm{p}=0.499$} & \multicolumn{2}{|c|}{$\mathrm{p}=0.515$} & \multicolumn{2}{|c|}{$\mathrm{p}=0.00202$} \\
\hline \multirow[t]{2}{*}{ Upper shelf/sea valley } & 0.047 & 0.10 & $3.5^{*}$ & $0.36^{*}$ & 0.44 & 0.40 \\
\hline & \multicolumn{2}{|c|}{$\mathrm{p}=0.0514$} & \multicolumn{2}{|c|}{$\mathrm{p}<0.001$} & \multicolumn{2}{|c|}{$p=0.540$} \\
\hline \multirow[t]{2}{*}{ Kodiak shelf } & $0.26^{*}$ & $0.076^{*}$ & $1.1^{*}$ & $0.59^{*}$ & $0.54^{*}$ & $0.18^{*}$ \\
\hline & \multicolumn{2}{|c|}{$p<0.001$} & \multicolumn{2}{|c|}{$\mathrm{p}<0.001$} & \multicolumn{2}{|c|}{$\mathrm{p}<0.001$} \\
\hline \multirow[t]{2}{*}{ Offshore } & 0.96 & 0.87 & $6.9^{*}$ & $2.6^{*}$ & $1.1^{*}$ & $0.24^{*}$ \\
\hline & \multicolumn{2}{|c|}{$p=0.427$} & \multicolumn{2}{|c|}{$p<0.001$} & \multicolumn{2}{|c|}{$\mathrm{p}<0.001$} \\
\hline
\end{tabular}

non-El Niño years. This standardization may to some extent reflect the relative success of larvae moving onshore. An increasing proportion of larvae in the nearshore regions indicated an accumulation of larvae. This indicator suggests that large and intermediate A. stomias larvae accumulate in the upper sea valley/ Amatuli Trough region, the outer Shelikof Strait sea valley and in the lower-shelf/Unimak Bight region. Accumulation over the lower-shelf would indicate

Table 5. Generalized linear model comparisons of the mean densities of Hippoglossus stenolepis in each stratum to the mean density of larvae in the offshore stratum in El Niño or non-El Niño years. Numbers in cells are the test statistic (deviance). If the Stratum $\times$ El Niño factor is significant, then the relative densities in these 2 strata change with El Niño conditions. ${ }^{*}$ Significant Stratum $\times$ El Niño effect after Bonferroni correction for multiple tests for an experimentwise error rate of 0.05: $\alpha=0.05 / 17=0.0029$. nd: no data

\begin{tabular}{|c|c|c|c|}
\hline \multirow{2}{*}{ Stratum } & \multirow[b]{2}{*}{$<13 \mathrm{~mm}$} & \multirow{2}{*}{$\begin{array}{l}\text { Length category } \\
13 \text { to } 18 \mathrm{~mm}\end{array}$} & \multirow[b]{2}{*}{$>18 \mathrm{~mm}$} \\
\hline & & & \\
\hline Lower shelf & nd & $\begin{array}{c}19^{*} \\
\mathrm{p}<0.001\end{array}$ & $\begin{array}{c}9.7^{*} \\
\mathrm{p}=0.0019\end{array}$ \\
\hline Middle shelf & $\begin{aligned} & 4.7 \\
\mathrm{p}= & 0.0308\end{aligned}$ & $\begin{array}{c}9.4^{*} \\
\mathrm{p}=0.0021\end{array}$ & $\begin{array}{c}44^{*} \\
\mathrm{p}<0.001\end{array}$ \\
\hline $\begin{array}{l}\text { Outer Shelikof } \\
\text { sea valley }\end{array}$ & $\begin{array}{c}11^{*} \\
\mathrm{p}=0.0010\end{array}$ & $\begin{array}{c}18^{*} \\
\mathrm{p}<0.001\end{array}$ & $\begin{array}{c}53^{*} \\
\mathrm{p}<0.001\end{array}$ \\
\hline $\begin{array}{l}\text { Inner Shelikof } \\
\text { sea valley }\end{array}$ & $\begin{array}{c}0.24 \\
\mathrm{p}=0.628\end{array}$ & $\begin{array}{c}19^{*} \\
\mathrm{p}<0.001\end{array}$ & $\begin{array}{c}87^{*} \\
\mathrm{p}<0.001\end{array}$ \\
\hline $\begin{array}{l}\text { Upper shelf/ } \\
\text { sea valley }\end{array}$ & $\begin{aligned} & 4.4 \\
\mathrm{p}= & 0.0356\end{aligned}$ & $\begin{array}{c}160^{*} \\
\mathrm{p}<0.001\end{array}$ & $\begin{array}{c}44^{*} \\
\mathrm{p}<0.001\end{array}$ \\
\hline Kodiak shelf & $\begin{array}{c}14^{*} \\
\mathrm{p}=0.0002\end{array}$ & $\begin{array}{c}9.1^{*} \\
p=0.0026\end{array}$ & $\begin{aligned} & 3.3 \\
\mathrm{p}= & 0.0683\end{aligned}$ \\
\hline
\end{tabular}

enhanced transport to the southwest during El Niño events. Large $H$. stenolepis larvae were accumulating in the lower-shelf/Unimak Bight region during El Niño events, and intermediate-sized larvae were accumulating in the upper-shelf/sea valley, outer Shelikof sea valley and lower-shelf regions. These results indicate relatively different transport conditions during El Niño and non-El Niño years.

Other explanations may be advanced for the relatively high abundances of Atheresthes stomias and Hippoglossus stenolepis larvae during El Niño conditions, including differences in spawning biomass, temperature effects on spawning location, biases in the surveys and differences in survival. We were able to test several of these factors, while the others remain as plausible factors under consideration. We tested the effect of differences in spawning biomass between the El Niño and non-El Niño years from data on $H$. stenolepis biomass (Clark \& Parma 1999); there was no significant difference (2-tailed $t$-test assuming unequal variances using the number of cruises $\mathrm{yr}^{-1}$ as a weighting factor, $\mathrm{p}=0.59$; El Niño mean $117.7 \times 10^{3} \mathrm{t}$ [metric tons], non-El Niño mean $=114.8 \times 10^{3} \mathrm{t}$ ). Even if the difference were statistically significant, the 1.02-fold difference in spawning biomass would not be enough to cause the 3- to 15-fold differences in larval abundance. It should be noted that the assessments for spawning biomass do not include a large portion of the area from Shelikof Strait to Unimak Pass (Clark \& Parma 1999). Likewise, for A. stomias the difference in biomass between El Niño and non-El Niño years was not significant (2-tailed $t$-test, $\mathrm{p}=0.12$; El Niño mean $=807.1 \times$ $10^{3} \mathrm{t}$, non-El Niño mean $=599.4 \times 10^{3} \mathrm{t}$ ). Again, it 
seems unlikely that a 1.3-fold difference in spawning biomass could account for 3 - to 60 -fold differences in larval abundance. However, it is possible that a large increase in biomass may cause a shift in the location of spawning. We tested possible bias in the timing of the surveys. The mean survey date did not vary significantly between the El Niño and non-El Niño years (2-tailed $t$-test, $\mathrm{p}=0.51$, El Niño mean survey date $=$ May 10, and non-El Niño mean survey date = May 3). Both species are planktonic for a protracted period, and even if statistically significant, the differences in mean survey date would not be expected to have a strong effect on abundance. With regards to a bias due to differences in areal coverage of the surveys, the cruises chosen for this analysis were based on their extensive coverage; although it is acknowledged that some areas were poorly covered in some years.

Bottom temperatures may be associated with a shift in spawning location of arrowtooth flounder and Pacific halibut. St. Pierre (1984) indicated that halibut may spawn in deep-sea valleys that penetrate the continental shelf. Bottom temperatures, as observed at $250 \mathrm{~m}$ at the University of Alaska's Station GAK (at the top of the Gulf of Alaska; $60^{\circ} \mathrm{N}, 149^{\circ} \mathrm{W}$ ), may be 0.5 to $1^{\circ} \mathrm{C}$ warmer during El Niño events (Bailey et al. 1995). These temperature anomalies may precede surface warming by several months, indicative of advection rather than surface heating due to atmospheric conditions (Royer \& Xiong 1984). However, in the Gulf of Alaska, variations in water column temperature are more closely related to a low-frequency cycle than to atmospheric indicators of El Niño conditions (Royer 1989). With regards to a shift in spawning location, data on spawning locations and their variations are not available, but an analysis of summer-time trawl survey data in El Niño and non-El Niño years did not show a significant El Niño effect on the distribution of arrowtooth flounder or Pacific halibut (Bailey et al. 1995).

The eggs of Atheresthes stomias and Hippoglossus stenolepis are likely farther offshore and deeper than the distribution of bongo tows in ICHBASE. In particular, $H$. stenolepis eggs have been frequently found below $200 \mathrm{~m}$ and even down to $700 \mathrm{~m}$ (Thompson \& Van Cleve 1936). They may also be prevalent in the water column earlier in the year than our usual surveys. In the case of A. stomias, the positive identification of eggs is as yet uncertain. As with the eggs of both species, most young larvae are probably farther offshore than our usual survey region, and the youngest stages of halibut larvae are deeper than the maximum depth of our tows $(200 \mathrm{~m})$. Thompson \& Van Cleve (1936) found that $H$. stenolepis larvae $<13 \mathrm{~mm}$ were mostly at 300 to $400 \mathrm{~m}$ depth but could be found as deep as $900 \mathrm{~m}$. As larvae of both species develop, they migrate into the upper water column and move inshore, where they are vulnerable to our sampling gear. Therefore the data that we have analyzed encompasses the inshore portion of the larval distribution and may not adequately represent the overall abundance of larvae. However, the abundance of larvae in our survey region probably gives a good picture of the processes whereby they reach their inshore nurseries from the offshore pool of larvae, and possibly represents the distribution of eventual survivors.

ENSO (El Niño-Southern Oscillation) conditions and warm-year anomalies are linked to year-class strength for Pacific halibut (see Fig. 10). We have not utilized the recruitment time series of arrowtooth flounder because most of the historical series depends on an age-length relationship derived from samples collected in 1984 and are applied to length frequencies from other years under the assumption of constant growth conditions (T. Wilderbuer pers. comm.). In spite of relatively similar life histories and larval transport patterns, it is not necessarily expected that these 2 species would have similar recruitment patterns, because the central Gulf of Alaska is at the northern end of the range of Hippoglossus stenolepis and at the southern end of the range of Atheresthes stomias. Juvenile A. stomias prefer colder nursery habitats (Norcross et al. 1999) and the northern Gulf of Alaska is at the warm end of their preferred habitat. Conversely, juvenile $H$. stenolepis prefer warmer nursery habitats, and the northern Gulf of Alaska is at the cold end of their preferred habitat (Norcross et al. 1999). The influence of critical factors such as larval transport on recruitment may vary over the range of a species because species life history traits vary over their ranges (Miller et al. 1991). Enhanced transport of larvae onshore and towards Unimak Bight may contribute to the tendency for relatively strong-year classes of Pacific halibut in the Gulf of Alaska during El Niño years. This may not be the case for arrowtooth flounder, because juvenile arrowtooth flounder prefer colder water. Thus, the benefit of enhanced onshore transport may be offset by less desirable temperatures.

Several studies have correlated recruitment (to the fishery) of Hippoglossus stenolepis with biotic and abiotic factors. Parker (1989) found that recruitment is density-dependent but is also influenced by strong winter winds, which favor production of strong yearclasses. It was suggested that alongshore and crossshelf winds generated transport conditions favorable for survival. Parker (1989) also suggested bathymetric steering of currents. For example, an accelerated Alaska Coastal Current could entrain offshore waters up troughs. Schumacher \& Reed (1980) suggested this as a key avenue for directing larvae in the Gulf of Alaska toward inshore nurseries. More recently, Parker et al. (1995) correlated low-frequency (smoothed) 


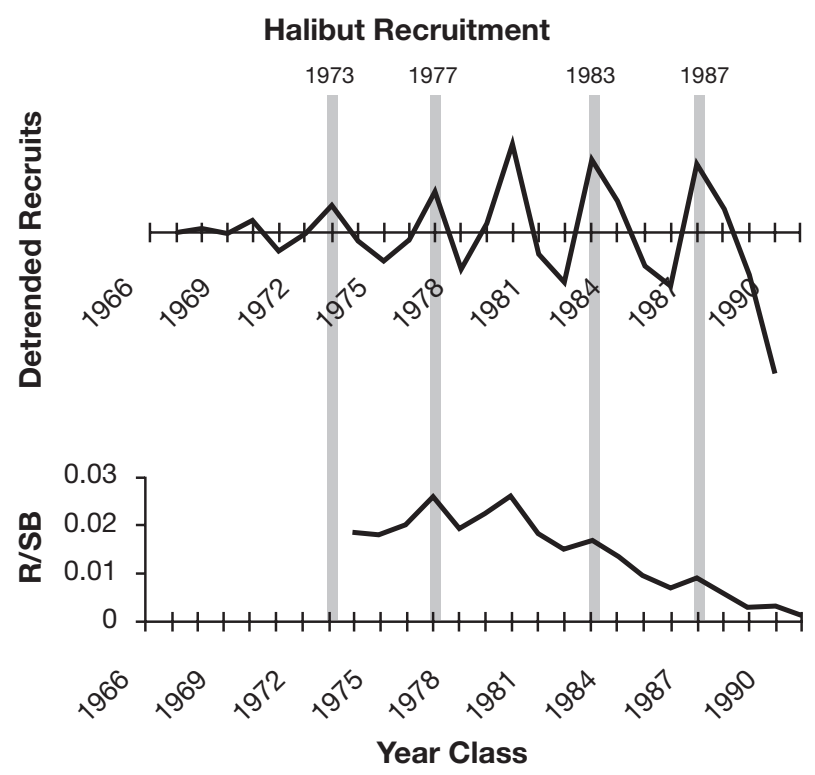

Fig. 10. Comparison of Hippoglossus stenolepis recruitment anomalies (top panel), calculated as the deviation from the 5 yr running mean, and R/SB (recruits per spawning biomass, bottom panel) to El Niño events, indicated by labeled vertical lines. Pacific halibut recruitment and spawning biomass data provided by the International Pacific Halibut Commission (Clark \& Parma 1999)

trends in halibut recruitment with an 18.6 yr lunar nodal cycle that is associated with tidal mixing. This lunar cycle was also found concordant with catches of groundfish species in the NW Atlantic Ocean (Cabilio et al. 1987). Enhanced tidal mixing might increase productivity and in addition be associated with enhanced conditions for inshore larval transport. In the years since a climate regime shift occurred in 1976-77 in the North Pacific, recruitment of $H$. stenolepis has increased dramatically (Clark et al. 1999), and while oceanographic and biological changes have been well documented, the biological mechanisms underlying recruitment variations are less well understood.

We suggest from our study that sea valleys and troughs appear to serve as transport pathways for Atheresthes stomias and Hippoglossus stenolepis larvae from their offshore spawning locations to inshore nurseries. During El Niño years, the abundance of $A$. stomias and $H$. stenolepis larvae over the shelf and outer-slope region of our surveys is enhanced, perhaps indicating more onshore transport. As well, there appears to be enhanced transport to the southwest toward Unimak Bight; larvae spawned in the Gulf of Alaska may eventually enter the Bering Sea (Skud 1977). There is likely a complicated interaction between the net direction of transport in bottom and near-surface currents as the larvae develop and move toward the surface. Both from the perspective of this study of larval distribution and from previous studies of correlations between recruitment and environmental factors, it appears that transport conditions are an important component, among the multitude of factors, that influence year-class formation. Onshore transport events may occur in other years, and strong yearclasses may occur in non-El Niño years for other reasons. For example, the strong 1980 year-class of $H$. stenolepis cannot be attributed to an El Niño effect (Fig. 10). Unfortunately icthyoplankton surveys are not available from that year to examine larval distribution patterns. Future research should examine the role of oceanographic processes in specific locales that may cause enhanced transport of larvae inshore in prominent transport pathways. The interaction of ontogenetic changes in vertical distribution and vertical migration also needs to be examined in relation to ocean processes such as tidal currents and shear in the water column. Such a linkage of behavior with predictable conditions that enhance transport (tidal stream transport) or retention has been found in other flatfish species (Gibson 1997).

Acknowledgements. We thank A. Kendall Jr and J. DuffyAnderson for comments on an early version of the manuscript, $\mathrm{T}$. Wilderbuer for discussions about arrowtooth flounder stock assessment, J. Turnock for data on arrowtooth flounder spawning biomass, and A. Parma and W. Clark of the International Pacific Halibut Commission for the stock and recruitment time series for Pacific halibut. Comments of anonymous reviewers are also appreciated. This is a contribution of the FOCI program.

\section{LITERATURE CITED}

Bailey KM, Macklin SA, Reed RK, Brodeur RD and 9 others (1995) The 1991-92 ENSO in the Gulf of Alaska and effects on selected marine fisheries. Calif Coop Oceanic Fish Invest Rep 36:78-96

Bailey KM, Bond N, Stabeno P (1999) Anomalous transport of walleye pollock larvae linked to ocean and atmospheric patterns in May 1996. Fish Oceanogr 8:264-273

Cabilio P, DeWolfe DL, Daborn GR (1987) Fish catches and long-term tidal cycles in Northwest Atlantic fisheries: a nonlinear regression approach. Can J Fish Aquat Sci 44: 1890-1897

Clark WG, Parma (1999) Assessment of the Pacific halibut stock in 1999. International Pacific Halibut Commission, Seattle, WA

Clark WG, Hare SR, Parma AM, Sullivan PJ, Trumble RJ (1999) Decadal changes in growth and recruitment of Pacific halibut (Hippoglossus stenolepis). Can J Fish Aquat Sci 56:242-252

Doherty PJ, Planes S, Mather P (1995) Gene flow and larval duration in seven species of fish from the Great Barrier Reef. Ecology 76:2373-2391

Gibson RN (1997) Behaviour and the distribution of flatfishes. J Sea Res 37:241-256

Lagerloef G (1983) Topographically controlled flow around 
a deep trough transecting the shelf off Kodiak Island, Alaska. J Phys Oceanogr 13:139-146

Miller JM, Burke JS, Fitzhugh GR (1991) Early life history patterns of Atlantic North American flatfish: likely (and unlikely) factors controlling recruitment. Neth J Sea Res 27:261-275

Minami T, Tanaka M (1992) Life history cycles in flatfish from the northwestern Pacific, with particular reference to their early life histories. Neth J Sea Res 29:35-48

Norcross BL, Blanchard A, Holladay BA (1999) Comparison of models for defining nearshore flatfish nursery areas in Alaskan waters. Fish Oceanogr 8:50-67

Parker KS (1989) Influence of oceanographic and meteorological processes on the recruitment of Pacific halibut, Hippoglossus stenolepis, in the Gulf of Alaska. In: Beamish RJ, McFarlane GA (eds) Effects of ocean variability on recruitment and an evaluation of parameters used in stock assessment models. Can Spec Publ Fish Aquat Sci No.108, p 221-237

Parker KS, Royer TC, Deriso RB (1995) High-latitude climate forcing and tidal mixing by the 18.6-year lunar nodal cycle and low-frequency recruitment trends in Pacific halibut (Hippoglossus stenolepis). In: Beamish RJ (ed) Climate change \& northern fish populations. Can Spec Publ Fish Aquat Sci No 121, p 449-459

Parrish RH, Nelson CS, Bakun A (1981) Transport mechanisms and reproductive success of fishes in the California Current. Biol Oceanogr 1:175-203

Rickey MH (1995) Maturity, spawning, and seasonal movement of arrowtooth flounder, Atheresthes stomias, off Washington. Fish Bull 93:127-138

Royer TC (1989) Upper ocean temperature variability in the northeast Pacific Ocean: is it an indicator of global warming? J Geophys Res 94:18175-18183

Royer TC, Xiong Q (1984) A possible warming in the Gulf of

Editorial responsibility: Otto Kinne (Editor),

Oldendorf/Luhe, Germany
Alaska due to the 1982-83 El Niño Southern Oscillation. Trop Ocean-Atmosph Newsl 24:4-5

St. Pierre G (1984) Spawning locations and season for Pacific halibut. Int Pac Halibut Comm Sci Rep 70

St. Pierre G (1989) Recent studies of Pacific halibut postlarvae in the Gulf of Alaska and eastern Bering Sea. Int Pac Halibut Comm Sci Rep 73

Schumacher JD, Reed RK (1980) Coastal flow in the northwest Gulf of Alaska: the Kenai Current. J Geophys Res 85: $6680-6688$

Sinclair M (1988) Marine populations: an essay on population regulation and speciation. Washington Sea Grant Press, Seattle

Skud BE (1977) Drift, migration, and intermingling of Pacific halibut stocks. Int Pac Halibut Comm Sci Rep 63:42

Stabeno P, Reed RK, Schumacher JD (1996) The Alaska coastal current: continuity of transport and forcing. J Geophys Res 100:2477-2485

Stepien CA (1999) Phylogeographical structure of the Dover sole Microstomus pacificus: The larval retention hypothesis and genetic divergence along the deep continental slope of the northeastern Pacific Ocean. Mol Ecol 8: 923-939

Thompson WF, Van Cleve R (1936) Life history of the Pacific halibut. Rep Int Fish Comm 9:1-184

Van der Veer HW, Witte JIJ (1999) Year-class strength of plaice Pleuronectes platessa in the Southern Bight of the North Sea: a validation and analysis of the inverse relationship with winter seawater temperature. Mar Ecol Prog Ser 184:245-257

Van der Veer HW, Ruardij P, Van den Berg AJ, Ridderinkho H (1998) Impact of interannual variability in hydrodynamic circulation on egg and larval transport of plaice Pleuronectes platessa L. in the southern North Sea. J Sea Res 39:29-40

Submitted: April 18, 2001; Accepted: October 25, 2001 Proofs received from author(s): May 22, 2002 